\title{
Is There a Caring Class? Intergenerational Transmission of Care Work
}

\author{
Maria Charles, ${ }^{a}$ Corrie Ellis, ${ }^{a}$ Paula England ${ }^{b}$
}

a) University of California, Santa Barbara; b) New York University

\begin{abstract}
Most research on intergenerational social reproduction has been concerned with upward and downward movements across rank-ordered, "big-class" categories or along continuous gradients of status, income, or skill. An exception is the more nominal conceptualization of the social structure offered in recent research that focuses on qualitative differences in life conditions across occupational "microclasses." The present analysis broadens this nominal approach by considering social reproduction across an important qualitative dimension that bridges multiple occupations: whether or not one's work centrally involves care. Based on data from the U.S. General Social Surveys, results provide little evidence that care work is transmitted from parents to children. While women and men whose parents worked in care are more likely to do so themselves, this association is attributable to a general tendency for people to work in the same detailed occupation as their parents. Parents pass along their vertical status positions, and sometimes their specific occupations, but not care work as such. Parent-child similarity in caring outcomes likely reflects transmission of values, skills, knowledge, and network ties that are specific to detailed occupations, rather than attributable to care work broadly defined.
\end{abstract}

Keywords: care; class; inequality; mobility; occupations; work

Citation: Charles, Maria, Corrie Ellis, and Paula England. 2015. "Is There a Caring Class? Intergenerational Transmission of Care Work." Sociological Science 2: 527-543.

Received: July 13, 2015

Accepted: July 17, 2015

Published: September 30, 2015

Editor(s): Jesper Sørensen, Kim Weeden

DOI: $10.15195 / \mathrm{v} 2 . \mathrm{a} 25$

Copyright: (C) 2015 The Author(s). This open-access article has been published under a Creative Commons Attribution License, which allows unrestricted use, distribution and reproduction, in any form, as long as the original author and source have been credited. (0)(1)
T is well established that children's socioeconomic outcomes depend upon their 1 parents' positions. Sociologists have long conceptualized these positions in terms of continuous hierarchies of income and prestige or of ordinal, "big-class" class categories. An exception is recent work that calls for greater attention to nominal "microclasses," or occupations (Weeden and Grusky 2005; Jonsson et al. 2009). Occupations are important loci of social reproduction, argue these authors, because incumbents share experiences, value orientations, and stocks of economic, social, and cultural capital that differ qualitatively and may be transmitted across generations.

Our analyses explore parental influences further by considering mobility across a nominal divide that is less fine-grained than the occupation but still represents an important qualitative dimension of the labor process. Using data from the U.S. General Social Surveys (GSS), we explore whether sons and daughters tend to follow their parents into the broad sector of work that is defined by a central focus on caring. Of particular interest is whether respondents whose parents provided care, either in the market or full-time in the home, are more likely to do care work themselves. As we define the term, care work involves provision of a face-to-face service that contributes to people's capabilities or physical maintenance (England, Budig, and Folbre 2002). 
Results provide little evidence that care work is transmitted from parents to children. While women and men are more likely to work in care if their parents did so, this association is attributable to the tendency for people to work in the same detailed occupation as their parents, especially their same-sex parent. Parents pass along their vertical status positions, and sometimes their occupations, but not care work as such. Parent-child similarity in caring outcomes likely reflects transmission of values, skills, knowledge, and network ties that are specific to detailed occupations, rather than attributable to care work broadly defined.

\section{Parental Influences on Work Roles}

Most previous research on intergenerational status attainment and mobility has been concerned with upward and downward movements across rank-ordered class categories or continuous gradients of socioeconomic status, income, or skill (Blau and Duncan 1967; Jencks et al. 1979; Erickson and Goldthorpe 1992; Hout and Hauser 1992; Chadwick and Solon 2002; Smeeding, Erikson, and Jäntti 2011). When occupations are grouped, it is typically into "big class" categories, based on skill levels, status, authority, or relationship to capital. An alternative, more purely nominal conceptualization of the social structure is offered in recent work by Weeden and Grusky (2005), who argue that detailed occupations (microclasses) are more proximate determinants of life chances and other individual outcomes than are either the gradational measures used for status attainment models or the ordinal, big-class categories used for traditional mobility-table analysis. By applying a detailed "class map" to patterns of social reproduction, Jonsson et al. (2009) find evidence of strong microclass reproduction that is consistent with intergenerational transmission of occupation-specific knowledge, skills, network ties, and values.

We contribute to this line of inquiry by exploring a new big-class model of social reproduction, but one in which classes are defined with respect to a key nominal dimension of the social structure: whether or not one's work centrally involves care. This dimension spans occupational microclasses, is only weakly related to the standard vertical scales, ${ }^{1}$ and is very gendered and racialized (Charles and Grusky 2004; Duffy 2011; Folbre 2012).

If dimensions of occupations' task content are reproduced intergenerationally, it seems likely that care would be one such dimension. Qualitative research suggests that interpersonal care is a highly salient feature of the labor process (HondagneuSotelo 2001; Borris and Parreñas 2010). Care workers and their employers and clients commonly understand care as a personal calling, or as something that certain categories of people, especially women and members of certain racial and ethnic groups, are naturally good at (Glenn 2010; Stacey 2011; Showers 2013). Those who feel a moral obligation to care, who are particularly good at care work (or think they are), or who have social ties to care-working gatekeepers may well have acquired the relevant values, skills, or network ties from their parents.

Mechanisms underlying intergenerational social reproduction include class- and gender-specific childrearing practices, genetic inheritance, and children's differential exposure to value orientations, job-relevant skills, socioeconomic resources, and social networks (Kohn 1977; Bem 1981; Bourdieu 1984; Granovetter 1995; Jonsson 
et al. 2009; Damaske 2011; Johnson and Mortimer 2011; Lareau 2011). Although most of these intervening mechanisms are not directly captured in our regression analyses, our models of intergenerational transmission of care work are followed by models exploring whether respondents' values relevant to care are influenced by parental care work. Mothers and fathers can have enduring effects on their children's attitudes and orientations through ongoing role-modeling, application of sanctions and rewards, or transfers of knowledge and resources (Marini and Brinton 1984; Glass, Bengston, and Dunham 1986; Jodl et al. 2001; Hitlin 2006; Wilhelm et al. 2008). If care-working parents transmit more altruistic values, these values may in turn motivate pursuit of care work by their children.

\section{Data and Methods}

The General Social Survey (GSS), conducted by the National Opinion Research Council, has been carried out annually from 1972 to 1994 (except in 1979, 1981, and 1992), and then every two years. Unlike many other nationally representative surveys, the GSS includes information on respondents' parents' employment status and occupations. For our analyses of intergenerational transmission of care work we optimize statistical power by using all available surveys between 1977 and 2010 (23 survey waves). Surveys prior to 1977 include no information on nativity, a control variable, and surveys after 2010 use a substantially different occupational classification (discussed further on). For analysis of care-working parents' influence on their children's values, we use data from GSS altruism modules administered in 2002, 2004, 2012, and 2014.

Following England, Budig, and Folbre (2002), we define "care" as work entailing a face-to-face service that contributes to people's capabilities (e.g., their health or skills) or physical maintenance (e.g., keeping children clean and safe). ${ }^{2}$ This includes occupations as diverse in status as physician, nurse, school teacher, home health aide, nursing home attendant, and childcare provider. We have experimented with alternative occupational typologies involving more restrictive definitions. Following Duffy and colleagues (Duffy 2011; Duffy, Albelda, and Hammonds 2013), for example, we have run sensitivity tests that eliminated from our care category librarian jobs and teaching that is not directed at children (professors and other postsecondary and adult educators), and we have tested specifications that included caretakers of animals (e.g., veterinarians). Results are robust to definitional changes with a few minor exceptions that are noted in the text.

Because the occupational structure changes over time, the U.S. Census Bureau adjusts periodically the typology it uses to distinguish occupations. To maintain as much historical continuity as possible, the GSS applied the 1970 Census classification of occupations until 1990, the 1980 Census classification from 1988 to 2010, and the 2010 Census classification starting in 2012. We harmonize the 1970 and 1980 codes using an occupational crosswalk (Weeden 2005). ${ }^{3}$ Because of large discrepancies between the 2010 and 1970 Census classification of occupations, extension of our survey period beyond 2010 would reduce the precision of our occupational classification substantially. We therefore use the 2012 and 2014 data for supplemen- 
tary analyses of attitudinal mechanisms but not for analyses of intergenerational inheritance.

In the appendix, Table A1 lists occupations coded as care for our primary analyses, Table A2 shows the largest care occupations for men and women by survey decade, ${ }^{4}$ and Table A3 shows the percentage of employed, working-age respondents working in care occupations by decade and sex. ${ }^{5}$ The latter table shows that the share of women who were care workers increased during the survey period (from 21 percent to 25 percent of respondents), while the share of men who were care workers remained stable at around seven percent. ${ }^{6}$ Both male and female respondents have maintained a strong presence in credentialed occupations in the teaching and medical fields, although men are clearly more concentrated at the higher-prestige levels of care work in all decades.

We model parental effects on propensities to care using a series of multilevel logistic regression models, with intercepts allowed to vary across years to account for possible clustering of cases by survey year. ${ }^{7}$ The primary analyses explore effects of parents' care work on the log-odds that respondents will do paid care work. We estimate models separately for men and women to allow for gender differences in the processes of social reproduction-in particular to identify effects of the same-sex parent (Aschaffenburg 1995; Moen, Erickson, and Dempster-McClain 1997; Beller 2009). Samples are restricted to employed persons of prime working age, defined as 25 to 64 years old.

Our primary question is whether the propensity to engage in paid care work is transmitted intergenerationally. Focal covariates are dummy indicators of parental care work. To classify parents as care workers, we use retrospective responses to the question, "What kind of work did your father/mother (or substitute) ${ }^{8}$ normally do while you were growing up?" Effects of paid maternal and paternal care work are assessed in separate models because the available occupational data cover different time periods (1994-2010 for mothers and 1977-2010 for fathers). We are able to examine effects of full-time maternal homemaking on respondents' occupational outcomes for the entire 1977-2010 period. Mothers who were not employed when the respondent was growing up are coded as "homemakers with care responsibilities," since we assume that the respondent was in their care. Including this predictor in our models allows us to test for maternal care effects on respondents' care outcomes that cross the market-domestic divide.

To improve our estimation of intergenerational transmission, we control for factors that may be correlated with parental and respondent care work. These include indicators of respondent's educational attainment and parents' occupational prestige. The latter allows us to assess the transmission of care work independently from the transmission of gradational social position, which has been well documented already (Jencks et al. 1979; Solon 1992; Bowles and Gintis 2002; Smeeding, Erikson, and Jäntti 2011). Parental occupational prestige is measured using the Hodge-Siegel-Rossi scores included with the GSS data, and respondents' education is measured as years of schooling.

Race, ethnicity, and nativity may also be correlated with care work of parents and respondents (Glenn 2010; Borris and Parreñas 2010; Dwyer 2013). To measure parental care effects net of these factors, we used information provided by 
respondents on their racial identification, family's country of origin, and birthplace. Persons claiming Mexico, Puerto Rico, Spain, or other Spanish-speaking countries as a country of origin are classified as Hispanic, and those claiming Japanese, Chinese, Indian, Philippine, or other Asian origins are classified as Asian. ${ }^{9}$ Respondents not claiming Asian or Hispanic origins are assigned to the Black, White, or "Other" category, based on information provided in the original GSS race variable. After reassignment of the Hispanic and Asian respondents, the final "Other" category is mostly composed of Native Americans, Arabs, and persons reporting themselves as mixed-race or not specifying a race. Our regression models include dummy indicators for black, Hispanic, Asian, and other, with white as the omitted category. We coded respondents as immigrants if they report birth outside of the United States. We have experimented with other coding schemes, including separate variables for race and ethnicity; conclusions regarding care are unchanged.

Models also include controls for age and survey period. Age and age-square terms are included to allow for nonlinear life course effects on propensities to care. Age is centered to reduce the correlation of the linear with the quadratic term. To assess effects of time, we break surveys into three periods roughly corresponding to the 1980s, 1990s, and 2000s: 1977-1989, 1990-1998, and 2000-2010, with the earliest period serving as the reference category. ${ }^{10}$ Our broad conclusions are unchanged if we use a linear or a quadratic specification to assess year effects, or if we use year-specific dummies (fixed effects) to control for time.

We explore the mechanisms of inheritance further by computing an analogous series of models that excludes respondents who work in the same detailed occupation as the parent in question (mother or father, depending on the parental effect considered). This allows us to investigate the extent to which intergenerational transmission of care, if found, is explained entirely by a more general tendency for children to go into the same detailed occupation (microclass) as their parents.

Finally, to explore the intergenerational transmission of care-relevant values, we model respondent attitudes as a function of parental care work. The 2002, 2004, 2012, and 2014 GSS surveys included topical modules on altruism. One particularly relevant survey item asked respondents to report the frequency with which they "feel a selfless caring for others" (ranging from "many times a day" to "never"). We treat this as an indicator of altruism, which might reasonably be transmitted from care-working parents and in turn motivate pursuit of care work. We use standard logistic regression models to assess effects of parental care on the log-odds that respondents report feelings of selfless caring on at least "most days" (as opposed to "some days," "once in a while," or "never"). Control variables are the same as in models predicting respondents' care work except that the decade dummies are replaced with three dummy indicators for year, and parental prestige (not available after 2010) is replaced with an indicator for parental university degree. We have conducted a variety of sensitivity tests using alternative coding schemes and diverse altruism measures; parental care effects are consistent across indicators.

In brief, our analytical plan is to present models assessing effects of parental paid or unpaid care work (taken separately) on the following outcomes: (1) respondents' paid care work; (2) paid care work among respondents not pursuing the same occupation as their parent; and (3) respondents' reported altruism. 
Table 1: Means (Standard Deviations) by Care Status

\begin{tabular}{lcc}
\hline & Care Workers & Non-Care Workers \\
\hline Care-employed Father? $^{a}$ Care-employed Mother $^{a}$ & 0.07 & 0.04 \\
Homemaking Mother? Father's Occupationall Prestige & 0.50 & 0.46 \\
Mother's Occupational Prestige $^{a}$ & 0.29 & 0.32 \\
& 43.26 & 40.99 \\
Age & $(15.29)$ & $(13.73)$ \\
& 40.36 & 38.63 \\
Education & $(14.68)$ & $(14.83)$ \\
& 41.26 & 41.24 \\
Black? $_{\text {Other Race? }}$ & $(10.40)$ & $(10.47)$ \\
Hispanic? $_{\text {Asian? }}$ & 15.56 & 13.33 \\
Immigrant? $_{\text {Ethos of Care? }}^{b}$ & $(2.92)$ & $(2.78)$ \\
\hline
\end{tabular}

Notes: Statistics are for employed, working-aged respondents to the 1977-2010 GSS, except: ${ }^{a} 1994-2010$ surveys; ${ }^{b} 2002,2004,2012$, and 2014 surveys.

\section{Results}

Table 1 shows descriptive statistics for variables in our regression models, broken down by care status. Bivariate comparisons provide support for the idea that care might be transmitted intergenerationally: respondents working in care occupations are indeed more likely to have had mothers and fathers who were paid care workers. Our regression models will allow us to assess the statistical significance of this intergenerational association while holding constant parents' occupational prestige and respondents' demographic characteristics. Care workers are on average better educated and have higher-prestige parents, which is not surprising given the list of largest care occupations shown in Table A2 in the appendix. Consistent with recent ethnographic studies, bivariate comparisons also indicate that respondents employed in care are more likely to report frequently feeling a "selfless caring for others." 11 Further on, we explore through multivariate analysis whether the odds that respondents report this "ethos of care" are higher among those with care-working parents.

\section{Is the Propensity to Care Transmitted Intergenerationally?}

Models predicting whether employed respondents work in paid care occupations are shown in Table 2. The first set of models (1a and $1 b)$ assesses effects of father's occupation on women's and men's log-odds of doing care work, the second set (2a 
and $2 b$ ) assesses effects of mother's paid occupation, and the third set ( $3 a$ and $3 b$ ) assesses effects of full-time maternal homemaking. In all of Table 2, the sample is limited to employed persons aged 25-64, and whether or not respondents do paid care work is the dependent variable.

Results of models 1 and 2 indeed show higher odds of doing paid care work for respondents whose parents are paid care workers, with stronger effects of the same-sex parent. Holding constant all other covariates, having a father who worked in a care occupation increases men's odds of doing so by 54 percent $(\exp [0.430]=$ 1.54), while a care-working mother increases men's odds by 46 percent. For women, the values are 19 percent for the father's effect and 25 percent for the mother's effect. Intergenerational transmission is somewhat stronger for men than women, possibly because the social and cultural forces propelling women into care are so diverse that effects of socialization in families of origin are relatively minor. ${ }^{12}$

The insignificant coefficients for maternal homemaking in models $3 \mathrm{a}$ and $3 \mathrm{~b}$ suggest that inheritance effects do not cross between paid and unpaid work domains; having had a mother who was doing care as a homemaker does not predict whether or not an employed woman or man will work in a care occupation. In supplementary analyses, we explored the reverse cross-sectoral effect: whether women whose parents did market-based care work are more likely to provide care full-time at home. ${ }^{13}$ Results (available on request) again showed no evidence of crossover between the domestic and market spheres. Although having had a homemaking mother significantly increased women's odds of homemaking herself, women were not more likely to become homemakers if one of their parents worked as a paid care worker.

Effects of control variables were mostly as expected. The gender-specific racial, ethnic, and nativity coefficients in Table 2 support previous research showing strong racial and gender dimensions to the social organization of care work in the United States (Hondagneu-Sotelo 2001; Glenn 2010; Dwyer 2013). Black and (to a lesser extent) immigrant women have higher odds than their white counterparts of working in care occupations, and Asian women have lower odds. For men, immigrants are less likely than those born in the United States to work in care, while those identifying as Hispanic, black, or other are more likely to do so than whites.

The positive effects of respondent's education are in line with bivariate results in Table 1 and with the relatively high prestige of the largest care occupations shown in Table A2 in the appendix. ${ }^{14}$ Less expected was the negative effect of parents' occupational prestige. It may be that parents in lower-prestige occupations place higher value on the relative job security and high social standing offered in medical and teaching fields. Given this negative net effect, it would appear that any positive effects of parental prestige on paid care work operate indirectly, through respondents' educational attainment. Sensitivity tests (available on request) show no significant interactions of parental prestige with parental care, meaning that intergenerational transmission is no stronger for parents in high-prestige care occupations than for those in low-prestige care occupations.

Indicators for decade suggest, if anything, that fewer work in care (relative to other occupations) over time. While this result appears to be at odds with the 
Table 2: Logistic Regression Models Predicting Incumbency in Care Occupations

\begin{tabular}{|c|c|c|c|c|c|c|}
\hline & $\begin{array}{l}\text { Women } \\
1 \mathrm{a}\end{array}$ & $\begin{array}{l}\text { Men } \\
1 b\end{array}$ & $\begin{array}{l}\text { Women } \\
2 \mathrm{a}\end{array}$ & $\begin{array}{l}\text { Men } \\
2 b\end{array}$ & $\begin{array}{c}\text { Women } \\
3 \mathrm{a}\end{array}$ & $\begin{array}{l}\text { Men } \\
3 b\end{array}$ \\
\hline $\begin{array}{l}\text { Care-employed } \\
\text { Father? }\end{array}$ & $\begin{array}{c}0.172 \\
(0.126)\end{array}$ & $\begin{array}{r}0.430^{\dagger} \\
(0.166)\end{array}$ & & & & \\
\hline $\begin{array}{l}\text { Care-employed } \\
\text { Mother? }\end{array}$ & & & $\begin{array}{r}0.223^{*} \\
(0.097)\end{array}$ & $\begin{array}{r}0.380^{*} \\
(0.167)\end{array}$ & & \\
\hline $\begin{array}{l}\text { Homemaking } \\
\text { Mother? }\end{array}$ & & & & & $\begin{array}{l}0.041 \\
(0.054)\end{array}$ & $\begin{array}{r}-0.123 \\
(0.094)\end{array}$ \\
\hline $\begin{array}{l}\text { Father's Occ. } \\
\text { Prestige }\end{array}$ & $\begin{array}{r}-0.009^{\dagger} \\
(0.002)\end{array}$ & $\begin{array}{r}-0.006^{*} \\
(0.003)\end{array}$ & & & & \\
\hline $\begin{array}{l}\text { Mother's Occ. } \\
\text { Prestige }\end{array}$ & & & $\begin{array}{r}-0.009^{\dagger} \\
(0.003)\end{array}$ & $\begin{array}{r}-0.012^{*} \\
(0.005)\end{array}$ & & \\
\hline $1990^{\prime} \mathrm{s}^{a}$ & $\begin{array}{c}-0.114 \\
(0.065)\end{array}$ & $\begin{array}{c}-0.147 \\
(0.113)\end{array}$ & & & $\begin{array}{r}-0.125^{*} \\
(0.061)\end{array}$ & $\begin{array}{c}-0.138 \\
(0.134)\end{array}$ \\
\hline $2000^{\prime} \mathrm{s}^{a}$ & $\begin{array}{c}-0.084 \\
(0.064)\end{array}$ & $\begin{array}{c}-0.197 \\
(0.109)\end{array}$ & $\begin{array}{c}0.078 \\
(0.078)\end{array}$ & $\begin{array}{c}-0.002 \\
(0.140)\end{array}$ & $\begin{array}{r}-0.059 \\
(0.060)\end{array}$ & $\begin{array}{r}-0.183 \\
(0.130)\end{array}$ \\
\hline $\mathrm{Age}^{b}$ & $\begin{array}{c}0.417 \\
(0.210)\end{array}$ & $\begin{array}{c}-0.102 \\
(0.472)\end{array}$ & $\begin{array}{l}0.025 \\
(0.447)\end{array}$ & $\begin{array}{r}-0.050 \\
(0.771)\end{array}$ & $\begin{array}{c}0.428 \\
(0.275)\end{array}$ & $\begin{array}{c}0.297 \\
(0.465)\end{array}$ \\
\hline Age-squared $^{b}$ & $\begin{array}{c}-0.004 \\
(0.024)\end{array}$ & $\begin{array}{r}0.110^{\dagger} \\
(0.040)\end{array}$ & $\begin{array}{c}0.018 \\
(0.035)\end{array}$ & $\begin{array}{c}0.137^{*} \\
(0.063)\end{array}$ & $\begin{array}{c}0.005 \\
(0.022)\end{array}$ & $\begin{array}{r}0.099^{+} \\
(0.038)\end{array}$ \\
\hline Education & $\begin{array}{r}0.313^{+} \\
(0.011)\end{array}$ & $\begin{array}{r}0.530^{\dagger} \\
(0.019)\end{array}$ & $\begin{array}{r}0.257^{+} \\
(0.016)\end{array}$ & $\begin{array}{r}0.486^{+} \\
(0.029)\end{array}$ & $\begin{array}{r}0.282^{+} \\
(0.010)\end{array}$ & $\begin{array}{r}0.536^{\dagger} \\
(0.018)\end{array}$ \\
\hline Black? $^{c}$ & $\begin{array}{r}0.348^{\dagger} \\
(0.079)\end{array}$ & $\begin{array}{l}0.413^{*} \\
(0.166)\end{array}$ & $\begin{array}{r}0.293^{+} \\
(0.100)\end{array}$ & $\begin{array}{l}0.344 \\
(0.216)\end{array}$ & $\begin{array}{r}0.425^{\dagger} \\
(0.066)\end{array}$ & $\begin{array}{r}0.574^{+} \\
(0.145)\end{array}$ \\
\hline Hispanic $^{c}$ & $\begin{array}{c}0.045 \\
(0.115)\end{array}$ & $\begin{array}{l}0.651^{\dagger} \\
(0.192)\end{array}$ & $\begin{array}{c}0.010 \\
(0.154)\end{array}$ & $\begin{array}{l}0.670^{*} \\
(0.265)\end{array}$ & $\begin{array}{c}-0.009 \\
(0.105)\end{array}$ & $\begin{array}{r}0.731^{\dagger} \\
(0.177)\end{array}$ \\
\hline Asian $?^{c}$ & $\begin{array}{r}-0.446^{*} \\
(0.183)\end{array}$ & $\begin{array}{c}0.044 \\
(0.257)\end{array}$ & $\begin{array}{c}-0.291 \\
(0.236)\end{array}$ & $\begin{array}{c}0.363 \\
(0.376)\end{array}$ & $\begin{array}{r}-0.524^{f} \\
(0.171)\end{array}$ & $\begin{array}{l}0.097 \\
(0.238)\end{array}$ \\
\hline Other & -0.090 & $0.925^{*}$ & -0.294 & $1.078^{*}$ & -0.407 & $0.796^{*}$ \\
\hline & $(0.291)$ & $(0.385)$ & $(0.407)$ & $(0.494)$ & $(0.287)$ & $(0.365)$ \\
\hline Immigrant? & $\begin{array}{c}0.168 \\
(0.104)\end{array}$ & $\begin{array}{r}-0.559^{\dagger} \\
(0.182)\end{array}$ & $\begin{array}{c}0.159 \\
(0.141)\end{array}$ & $\begin{array}{r}-0.731^{*} \\
(0.284)\end{array}$ & $\begin{array}{r}0.257^{+} \\
(0.094)\end{array}$ & $\begin{array}{r}-0.458^{\dagger} \\
(0.167)\end{array}$ \\
\hline Constant & $\begin{array}{r}-5.282^{+} \\
(0.168)\end{array}$ & $\begin{array}{r}-10.579^{+} \\
(0.339)\end{array}$ & $\begin{array}{r}-4.717^{+} \\
(0.247)\end{array}$ & $\begin{array}{r}-9.923^{+} \\
(0.505)\end{array}$ & $\begin{array}{r}-5.217^{\dagger} \\
(0.151)\end{array}$ & $\begin{array}{r}-10.925^{\dagger} \\
(0.325)\end{array}$ \\
\hline $\begin{array}{l}\text { Std. Dev. Ran- } \\
\text { dom Effect }\end{array}$ & 0.000 & 0.071 & 0.000 & 0.000 & 0.000 & 0.162 \\
\hline Log Likelihood & $-4,642.325$ & $-1,981.850$ & $-2,247.012$ & -840.612 & $-5,405.514$ & $-2,146.227$ \\
\hline Respondents (N) & 9,461 & 9,910 & 4,304 & 4,014 & 10,842 & 10,964 \\
\hline Survey Years (N) & 23 & 23 & 9 & 9 & 23 & 23 \\
\hline
\end{tabular}

Notes: Values are logistic coefficients (standard errors) from multilevel models with random effects for survey year. Samples are currently employed respondents aged 25-64 to the GSS of 1977-2010. Models 2a and $2 \mathrm{~b}$ cover $199-2010$ only.

$* p<0.05 ;+p<0.01$.

${ }^{a}$ Reference group is the eighties (1977-1988) for Models 1a, 1b, 3a, and 3b, and the nineties (1994-1998) for Models 2a and 2b.

${ }^{b}$ Age and Age-Squared coefficients and standard errors are multiplied by 100 to facilitate display.

${ }^{c}$ Reference group for race/ethnicity is white. 
upward trend for women shown in Table A3 in the appendix, the discrepancy can be attributed to correlations with educational attainment. Because women's movement into care work has been accompanied by their increasing investment in the requisite educational credentials for medical, teaching, and social work positions, the upward trend is eliminated when we compare women with equal levels of education. Age is also unrelated to women's incumbency in care. For men, we find nonlinear age effects indicating increasing representation starting at approximately age $40 .{ }^{15}$

\section{Does Inheritance Bridge Detailed Care Occupations?}

Results so far show a tendency for intergenerational reproduction of paid care work. To assess the meaning of this finding, we must consider the extent to which it goes beyond the general tendency for children to follow their parents into specific occupations.

Table 3 shows our basic models applied to samples that exclude respondents who work in the same detailed occupational category as the parent in question. With this sample restriction, all parental care effects are eliminated. It appears, then, that children inherit specific occupations from their parents, but not any general tendency to work in care occupations.

This negative result does not depend upon how we measure parents' social standing or on whether we include a control for parents' vertical status position. Table A4 in the appendix shows that effects of parental care work remain insignificant if parental occupational prestige is replaced with parental education, measured as university completion or measured on a continuous scale (years of education), or if we omit the control for parental vertical status altogether.

Our general conclusions are strengthened by results from supplementary multivariate models (available on request) showing that the tendency to work in the same detailed occupation as one's parent is no stronger when the parent is in a care occupation than in a non-care occupation. ${ }^{16}$ While occupations are clearly important conduits for social reproduction, we find no evidence for intergenerational transmission of any overarching propensity to do care work.

\section{Do Parents Transmit an Ethos of Care?}

Building on existing social psychological research, we compute a final set of logistic regression models exploring effects of parental care on attitudes, specifically whether a stronger sense of altruism (an "ethos of care") is transmitted by parents who do care work. Values in Table 4 give the net effects of parental care status on the log-odds that respondents report frequently feeling a "selfless caring for others." Models pertain to employed, working-age samples in 2002, 2004, 2012, and 2014, the years when the GSS altruism module was administered.

Results show few measurable effects of parental care status on reported altruism. One exception is that men (but not women) whose fathers worked in a care occupation are somewhat more likely to report that they feel "a selfless caring for others" on at least "most days." It is possible that values are more powerfully transmitted from parent to child when they are gender-nonconforming. Beyond 
Table 3: Logistic Regression Models Predicting Incumbency in Care Occupations, Excluding Respondents Working in the Parent's Occupation

\begin{tabular}{|c|c|c|c|c|}
\hline & $\begin{array}{c}\text { Women } \\
1 \mathrm{a}\end{array}$ & $\begin{array}{c}\text { Men } \\
1 b\end{array}$ & $\begin{array}{c}\text { Women } \\
2 \mathrm{a}\end{array}$ & $\begin{array}{l}\text { Men } \\
2 b\end{array}$ \\
\hline Care-employed Father? & $\begin{array}{c}-0.030 \\
(0.130)\end{array}$ & $\begin{array}{c}-0.047 \\
(0.182)\end{array}$ & & \\
\hline Care-employed Mother? & & & $\begin{array}{c}-0.094 \\
(0.103)\end{array}$ & $\begin{array}{c}0.230 \\
(0.172)\end{array}$ \\
\hline Father's Occupational Prestige & $\begin{array}{r}-0.007^{\dagger} \\
(0.002)\end{array}$ & $\begin{array}{c}-0.004 \\
(0.003)\end{array}$ & & \\
\hline Mother's Occupational Prestige & & & $\begin{array}{r}-0.009^{\dagger} \\
(0.003)\end{array}$ & $\begin{array}{r}-0.012^{*} \\
(0.005)\end{array}$ \\
\hline $1990^{\prime} \mathrm{s}^{a}$ & $\begin{array}{c}-0.103 \\
(0.065)\end{array}$ & $\begin{array}{c}-0.185 \\
(0.120)\end{array}$ & & \\
\hline $2000^{\prime} \mathrm{s}^{a}$ & $\begin{array}{c}-0.073 \\
(0.065)\end{array}$ & $\begin{array}{c}-0.211 \\
(0.116)\end{array}$ & $\begin{array}{c}0.097 \\
(0.080)\end{array}$ & $\begin{array}{c}-0.013 \\
(0.142)\end{array}$ \\
\hline $\mathrm{Age}^{b}$ & $\begin{array}{c}0.409 \\
(0.294)\end{array}$ & $\begin{array}{c}-0.008 \\
(0.480)\end{array}$ & $\begin{array}{c}-0.223 \\
(0.461)\end{array}$ & $\begin{array}{r}-0.042 \\
(0.783)\end{array}$ \\
\hline Age-squared $^{b}$ & $\begin{array}{c}-0.005 \\
(0.024)\end{array}$ & $\begin{array}{r}0.116^{+} \\
(0.041)\end{array}$ & $\begin{array}{c}0.017 \\
(0.036)\end{array}$ & $\begin{array}{r}0.135^{*} \\
(0.064)\end{array}$ \\
\hline Education & $\begin{array}{c}0.316^{+} \\
(0.011)\end{array}$ & $\begin{array}{r}0.525^{+} \\
(0.019)\end{array}$ & $\begin{array}{c}0.260^{\dagger} \\
(0.016)\end{array}$ & $\begin{array}{r}0.501^{+} \\
(0.030)\end{array}$ \\
\hline Black? $^{c}$ & $\begin{array}{r}0.347^{\dagger} \\
(0.079)\end{array}$ & $\begin{array}{r}0.397^{*} \\
(0.167)\end{array}$ & $\begin{array}{c}0.247^{*} \\
(0.103)\end{array}$ & $\begin{array}{c}0.414 \\
(0.218)\end{array}$ \\
\hline Hispanic? ${ }^{c}$ & $\begin{array}{c}0.049 \\
(0.115)\end{array}$ & $\begin{array}{c}0.624^{+} \\
(0.196)\end{array}$ & $\begin{array}{c}-0.046 \\
(0.158)\end{array}$ & $\begin{array}{r}0.732^{\dagger} \\
(0.268)\end{array}$ \\
\hline Asian $?^{c}$ & $\begin{array}{r}-0.475^{*} \\
(0.186)\end{array}$ & $\begin{array}{c}0.007 \\
(0.261)\end{array}$ & $\begin{array}{r}-0.325 \\
(0.242)\end{array}$ & $\begin{array}{c}0.342 \\
(0.378)\end{array}$ \\
\hline Other Race $?^{c}$ & $\begin{array}{c}-0.054 \\
(0.293)\end{array}$ & $\begin{array}{l}1.195^{+} \\
(0.389)\end{array}$ & $\begin{array}{c}-0.578 \\
(0.458)\end{array}$ & $\begin{array}{r}1.101^{*} \\
(0.496)\end{array}$ \\
\hline Immigrant? & $\begin{array}{c}0.163 \\
(0.104)\end{array}$ & $\begin{array}{r}-0.593^{+} \\
(0.186)\end{array}$ & $\begin{array}{c}0.192 \\
(0.143)\end{array}$ & $\begin{array}{r}-0.675^{*} \\
(0.287)\end{array}$ \\
\hline Constant & $\begin{array}{r}-5.358^{+} \\
(0.170)\end{array}$ & $\begin{array}{r}-10.489^{+} \\
(0.343)\end{array}$ & $\begin{array}{r}-4.731^{\dagger} \\
(0.253)\end{array}$ & $\begin{array}{r}-10.136^{\dagger} \\
(0.519)\end{array}$ \\
\hline Std. Dev. Random Effect & 0.000 & 0.097 & 0.000 & 0.000 \\
\hline Log Likelihood & $-4,565.113$ & $-1,895.226$ & $-2,134.006$ & -810.786 \\
\hline Respondents (N) & 9,234 & 9,037 & 4,117 & 3,919 \\
\hline Survey Years (N) & 23 & 23 & 9 & 9 \\
\hline
\end{tabular}

Notes: Values are logistic coefficients (standard errors) from multilevel models with random effects for survey year. Samples are currently employed respondents aged 25-64 to the GSS of 1977-2010. Models 1a and $1 \mathrm{~b}$ exclude respondents with the same occupation as their father. Models $2 \mathrm{a}$ and $2 \mathrm{~b}$ exclude respondents with the same occupation as their mother (1994-2010 only).

$* p<0.05 ;+p<0.01$.

${ }^{a}$ Reference group is the eighties (1977-1988) for Models 1a and 1b, and the nineties (1994-1998) for Models $2 \mathrm{a}$ and $2 \mathrm{~b}$.

${ }^{b}$ Age and Age-Squared coefficients and standard errors are multiplied by 100 to facilitate display.

${ }^{c}$ Reference group for race/ethnicity is white. 
Table 4: Effects of Parental Care Status on Respondents' "Ethos of Care"

\begin{tabular}{lcc}
\hline & Women & Men \\
Care-employed Father & -0.347 & $0.621^{*}$ \\
& $(0.278)$ & $(0.298)$ \\
Care-employed Mother & $\mathrm{N}=976$ & $\mathrm{~N}=1,026$ \\
& 0.070 & -0.091 \\
& $(0.128)$ & $(0.123)$ \\
Homemaking Mother? & $\mathrm{N}=1,236$ & $\mathrm{~N}=1,265$ \\
& 0.279 & 0.023 \\
& $(0.145)$ & $(0.133)$ \\
& $\mathrm{N}=1,278$ & $\mathrm{~N}=1,321$
\end{tabular}

Notes: Data are from the GSS of 2002, 2004, 2012, and 2014. Rows represent separate logistic regression analyses; values give net effects of parental care status on the log-odds of employed respondents' feeling "a selfless caring for others" on at least "most days" (standard errors in parentheses). Control variables are the same as in Table 2, except that the decade terms are replaced with dummy indicators for years 2004, 2012, and 2014, and parental prestige is replaced with an indicator for a parental university degree. The reference category for care-working father is employed father not in care work; the reference for care-working mother is employed mother not in care work. The reference for homemaking mother is mothers who worked for pay for a year or more while the respondent was growing up.

$* p<0.05$.

their mothers, girls are exposed to a vast array of interpersonal and cultural influences that encourage internalization and expression of an ethos of care (Glenn 2010; Ridgeway 2011). Boys may be more impressed by a father's devotion to the care of others. Moreover, given the cultural association of caring with femininity, boys may interpret their mothers' care work as hardwired and therefore irrelevant to their own career trajectories. However, previously discussed results suggest that any transmission of caring values from father to son is manifest in occupation-specific reproduction, not in a more general propensity to do paid care work. ${ }^{17}$

We have also considered responses to related items from the GSS altruism modules, individually and combined into indices. These include: "I often have tender, concerned feelings for people less fortunate than me;" "people should be willing to help others who are less fortunate;" "assisting people in trouble is very important to me;" and frequency of volunteering for charity. None are related to parental care status.

In light of the weak care-inheritance effects that we have documented, it is not surprising that altruistic attitudes (one mechanism by which care work might be transmitted from mothers and fathers) differ little between those growing up with and without care-working parents. Our results support research linking carerelevant values and attitudes to diverse experiences and influences that go beyond parents' work roles (Leira 1994; Hondagneu-Sotelo 2001; Borris and Parreñas 2010; Glenn 2010). The "caring self" may also be an identity constructed by care workers to give meaning to their care-giving experiences after the fact (Stacey 2011). 


\section{Conclusion}

The fundamental question motivating this analysis is whether a propensity to do care work is transmitted from parents. Results show that people whose parents worked in care are indeed more likely to do care work themselves. But this intergenerational similarity in caring outcomes is almost entirely attributable to the general tendency for children to go into the same detailed occupation as their parents, especially their same-sex parent. Our analyses of possible attitudinal mechanisms lend little support, moreover, to the idea that parents who work in care occupations or as full-time homemakers transmit "an ethos of care" that might orient their children toward paid care work. While care-working respondents are more likely to report feeling a "selfless caring for others," these reports are weakly related to their parents' care status.

This study contributes theoretically to emergent sociological debates on the structure of intergenerational social reproduction-specifically on the role of qualitative differences in the context, content, and process of work in shaping patterns of inequality and mobility. Proponents of a "new class map" argue that this structuration is best captured at the level of the detailed occupation (Weeden and Grusky 2005; Jonsson et al. 2009). Our negative findings lend support to these arguments and demonstrate that care, a single nominal dimension of the labor process that bridges multiple occupations (or multiple microclasses), is not itself reproduced intergenerationally. Parent-child similarity in caring outcomes likely reflects processes that are more fine-grained than can be captured with reference to a general "ethos of care" or care-relevant assets. Care-working parents may transmit values, networks, and human capital resources that are specific to detailed occupations, rather than generic to care work.

Beyond their theoretical contributions, these findings provide clues as to how patterns of parent-child inheritance might influence trends in social and economic inequality among care workers. Intergenerational inheritance of occupational microclass positions will more directly perpetuate existing patterns of racial, ethnic, and class inequality than would a broad "care sector" effect, which would bridge different types of care occupations and thereby allow possibilities for intergenerational income or status mobility. To the extent that the same-sex parent has a stronger influence, microclass inheritance will also help maintain existing patterns of occupational sex segregation within the care sector.

\section{Notes}

1 The care/non-care distinction is not unrelated to earnings, but the correlation is weak; under numerous controls, including individual fixed effects, wages are about five percent lower in care work (England, Budig, and Folbre 2002). This weak linear relationship is not surprising, given strong wage polarization within the care sector (Dwyer 2013). In the health sector alone, care workers span the income spectrum-from home health aides to physicians, for example.

2 This is roughly analogous to Duffy's (2011) and Dwyer's (2013) definitions of nurturant care workers. We exclude "reproductive" laborers, who engage in cooking and cleaning 
that less often involves face-to-face interaction. Classification of occupations as care or non-care was done independently by each of the three authors and an undergraduate research assistant. Inter-coder reliability was high. For discrepant cases, final coding decisions were made following group discussion. Results are robust to alternative classification of ambiguous cases.

3 Classification was based on the percentage of 1980-coded incumbents that fell into each 1970 category during the 1980 census. Using these weights, we assigned 1970 codes to 1980 occupations as follows: for 173 (of 503) 1980 categories, we were able to identify a single 100-percent match; for 272 categories, we assigned the 1970 category that accounted for the largest share of both male and female incumbents; for 58 cases where the largest category differed by sex, we assigned the sex-specific plurality category (i.e., we assigned female respondents to the 1970 occupation that accounted for the largest share of U.S. women and male respondents to the 1970 occupational that accounted for the largest share of U.S. men). Since some of the occupations are very sex-segregated, the within-sex largest category seemed a better guess than the overall largest category.

4 For the analyses of 2012 and 2014 data, we coded parents as care workers by matching as closely as possible those occupations coded as care for the primary analyses (2012/2014 list available on request).

5 Because respondent's occupation is measured on the survey date, rather than at a specific point in the life course (e.g., first job), we are better able to speak to change across historical time than across birth cohorts. Occupational outcomes are affected by age, cohort replacement, and secular historical trends (Yang and Land 2008). These effects cannot be clearly distinguished with these data.

6 During the same period, full-time homemaking (i.e., unpaid care work as a primary vocation) declined for women (from 30 percent to 16 percent of the sample), as female labor force participation increased. Men's participation in full-time homemaking remained in the one percent range, even after more than doubling from the 1990s to the 2000's.

7 Because the social and cultural environment varies by year, prediction errors may be correlated within surveys (Raudenbush and Bryk 2002; Luke 2004). If individual-level models are used for clustered data, standard errors may be too small and significance tests may be inaccurate. We use Stata's xtmelogit procedure with restricted maximum likelihood (REML) estimation. We have also estimated a series of standard logistic regression models, including some that fix the effect of time by including a complete set of dummy variables for year. Results are very similar to those shown in the tables. This is not surprising; the standard deviations of our random-effects parameters are small, suggesting little variability across survey years in respondents' propensities to do care work, net of individual-level traits. Most of the variability in respondents' odds of doing care work occurs within, not across, surveys.

8 "Substitute" refers to parental substitutes with whom the respondent lived as a child.

9 The ethnic affiliations of the three racial groups are as follows: 2.1 percent of blacks, 4.8 percent of whites, and 49.7 percent of Others reported Hispanic origins. 1.1 percent of Blacks, 0.5 percent of Whites, and 29.7 percent of Others reported Asians origins. A very small number reported both Hispanic and Asian origins. We privileged Hispanic origins in these cases. Starting in 2000, respondents were asked directly to identify as Hispanic or not. Comparison of these frequencies with those for our "country of origin" variable for 2000-2012 yields a very close match (10.5 percent and 10.6 percent Hispanic, respectively).

10 For models assessing effects of maternal care occupations (which cover only the 19942010 period), the reference category is 1994-1999. 
11 These mean differences are statistically significant and hold for both women and men.

12 The mother-to-son inheritance effect shrinks to statistical insignificance if we adopt Duffy's (2011) narrower definition of care that excludes librarians and postsecondary teachers (i.e., professors). Maternal effects on men also attenuate in models that control for both mothers' and fathers' occupations. It may be that transmission from mothers to sons is more likely for high-status occupations that are not stereotypically female.

13 For the purpose of this analysis, we defined respondents as "full-time homemakers with care responsibilities" if they reported keeping house as their labor force status and living in households comprised of two or more persons.

14 Among women, the mean prestige scores for care and non-care workers are 51.1 and 39.5, respectively. Among men, the values are 62.8 and 40.9 .

15 The same nonlinearities are found in models with fixed year effects, suggesting that they reflect age differences in propensity to do care work, not within-decade cohort effects.

16 Controlling for respondents' education and parents' occupational prestige, effects of parental care work on incumbency in the same detailed occupation are in fact negative in all but the mother-daughter models, where effects are insignificant.

17 The effect of paternal care on sons' attitudes is no longer statistically significant if we exclude post-secondary teachers (e.g., professors) and librarians from the analysis. One interpretation is that boys are more strongly influenced by fathers working in high-status care occupations.

\section{References}

Aschaffenburg, Karen E. 1995. "Rethinking Images of the Mobility Regime: Making a Case for Women's Mobility." Research on Social Stratification and Mobility 14:201-235.

Baker, David P. and Gerald K. LeTendre. 2005. National Differences, Global Similarities: World Culture and the Future of Schooling. Stanford: Stanford University Press.

Beller, Emily. 2009. "Bringing Intergenerational Social Mobility Research into the Twentyfirst Century" Why Mothers Matter." American Sociological Review 74:507-28. http: //dx.doi.org/10.1177/000312240907400401.

Bem, Sandra Lipsitz. 1981. "Gender Schema Theory: A Cognitive Account of Sex Typing." Psychological Review 88:354-64. http://dx.doi.org/10.1037/0033-295X .88.4.354.

Blau, Peter and O. D. Duncan. 1967. The American Occupational Structure. New York: Wiley.

Bourdieu, Pierre. 1984. Distinction: A Social Critique of the Judgment of Taste. Cambridge, MA: Harvard University Press.

Borris, Eileen and Rhacel Salazar Parreñas, eds. 2010. Intimate Labors: Cultures, Technologies, and the Politics of Care. Stanford: Stanford University Press.

Bowles, Samuel and Herbert Gintis. 2002. "The Inheritance of Inequality." Journal of Economic Perspectives 16:3-30. http://dx.doi.org/10.1257/089533002760278686.

Budig, Michelle J. and Joya Misra. 2010. "How Care-Work Employment Shapes Earnings in Cross-national Perspective." International Labour Review 149:441-60. http: //dx. doi .org/ 10.1111/j.1564-913X.2010.00097.x.

Chadwick, Laura and Gary Solon. 2002. "Intergenerational Income Mobility among Daughters" The American Economic Review 92:335-44. http://dx.doi.org/10.1257/ 000282802760015766. 
Charles, Maria and David Grusky. 2004. Occupational Ghettos: The Worldwide Segregation of Women and Men. Stanford: Stanford University Press.

Damaske, Sarah. 2011. “A 'Major Career Woman?' How Women Develop Early Expectations about Work." Gender E Society 25:409-30. http://dx.doi.org/10.1177/ 0891243211412050.

Duffy, Mignon. 2011. Making Care Count: A Century of Gender, Race, and Paid Care Work. New Brunswick, NJ: Rutgers.

Duffy, Mignon, Randy Albelda, and Clare Hammonds. 2013. "Counting Care Work: The Empirical and Policy Applications of Care Theory." Social Problems 60:145-67. http: //dx.doi.org/10.1525/sp.2013.60.2.145.

Dwyer, Rachel. 2013. "The Care Economy? Gender, Economic Restructuring and Job Polarization in the U.S. Labor Market." American Sociological Review 78:390-416. http: //dx.doi.org/10.1177/0003122413487197.

England, Paula. 2005. "Emerging Theories of Care Work." Annual Review of Sociology 31:381-99. http://dx.doi.org/10.1146/annurev.soc.31.041304.122317.

England, Paula and Nancy Folbre. 1999. "The Cost of Caring." Annals of the American Academies of Political and Social Sciences 561:39-51. http://dx.doi.org/10.1177/ 0002716299561001003.

England, Paula, Michelle Budig, and Nancy Folbre. 2002 “Wages of Virtue: The Relative Pay of Care Work." Social Problems 49:455-473. http://dx. doi .org/10.1525/sp. 2002 .49.4. 455.

Erikson, Robert and John H. Goldthorpe. 1992. The Constant Flux: A Study of Class Mobility in Industrial Societies. Oxford: Clarendon Press.

Folbre, Nancy, ed. 2012. For Love and Money: Care Provision in the United States. New York: Russell Sage Foundation.

Glass, Jennifer, Vern L. Bengston, and Charlotte Chorn Dunham. 1986. "Attitude Similarity in Three-Generation Families: Socialization, Status Inheritance, or Reciprocal Influence?" American Sociological Review 51:685-698. http://dx. doi .org/10.2307/2095493.

Glenn, Evelyn Nakano. 2010. Forced to Care: Coercion and Caregiving in America. Cambridge, MA: Harvard University Press.

Granovetter, Mark. 1995. Getting a Job: A Study of Contacts and Careers. Chicago: University of Chicago Press.

Hitlin, Steven. 2006. "Parental Influences on Children's Values and Aspirations: Bridging Two Theories of Social Class and Socialization." Sociological Perspectives 49:25-46. http: //dx.doi.org/10.1525/sop.2006.49.1.25.

Hochschild, Arlie R. 1983. The Managed Heart: The Commercialization of Human Feeling. Berkeley: University of California Press.

Hout, Michael, and Robert M. Hauser. 1992. "Hierarchy and Symmetry in Occupational Mobility." European Sociological Review 8:239-66.

Hondagneu-Sotelo, Pierrette. 2001. Doméstica: Immigrant Workers Cleaning and Caring in the Shadows of Affluence. Berkeley: University of California Press.

Jackson, Robert Max. 1998. Destined for Equality: The Inevitable Rise of Women's Status. Cambridge, MA: Harvard University Press.

Jencks, Christopher, Susan Bartlett, Mary Corcoran, James Crouse, David Eaglesfield, Gregory Jackson, Kent McClelland, Peter Mueser, Michael Olneck, Joseph Schwartz, Sherry Ward, and Jill Williams. 1979. Who Gets Ahead? The Determinants of Economic Success in America. New York: Basic Books. 
Jodl, Kathleen M., Alice Michael, Oksana Malanchuk, Jacquelynne S. Eccles, and Arnold Sameroff. 2001. "Parents' Roles in Shaping Early Adolescents' Occupational Aspirations." Child Development 72:1247-66. http://dx.doi .org/10.1111/1467-8624.00345.

Jonsson, Jan O., David B. Grusky, Matthew Di Carlo Reinhard Pollak, and Mary Brinton. 2009. "Microclass Mobility: Social Reproduction in Four Countries." American Journal of Sociology 114:997-1036. http://dx.doi.org/10.1086/596566.

Johnson, Monica Kirkpatrick and Jeylan T. Mortimer. 2011. “Origins and Outcomes of Judgments about Work." Social Forces 89:1239-60. http://dx. doi .org/10.1093/sf/89. 4.1239 .

Kohn, Melvin L. 1977. Class and Conformity: A Study in Values, Second Edition. Chicago: University of Chicago Press.

Lareau, Annette. 2011. Unequal Childhoods: Race, Class, and Family Life, Second Edition. A Decade Later. Berkeley: University of California Press.

Lee, Kristen Schultz. 2010. "Gender, Care Work, and the Complexity of Family Membership in Japan." Gender E Society 24:647-71. http://dx.doi.org/10.1177/ 0891243210382903.

Leira, Arnlaug. 1994. "Concepts of Caring: Loving, Thinking, and Doing." Social Service Review 68:185-200. http://dx.doi.org/10.1177/0891243210382903.

Luke, Douglas A. 2004. Multilevel Modeling. Thousand Oaks, CA: Sage Publications.

Marini, Margaret M. and Mary C. Brinton. 1984. "Sex Typing in Occupational Socialization." Pp. 192-232 in Sex Segregation in the Workplace: Trends, Explanations, Remedies, edited by Barbara Reskin. Washington: National Academy Press.

Moen, Phyllis, Mary Ann Erickson, Donna Dempster-McClain. 1997. “Their Mother's Daughters? The Intergenerational Transmission of Gender Attitudes in a World of Changing Roles." Journal of Marriage and Family 59:281-293. http://dx.doi.org/10. 2307/353470.

Raudenbush, Stephen W. and Anthony S. Bryk. 2002. Hierarchical Linear Models: Applications and Data Analysis Methods. Newbury Park, CA: Sage Publications.

Ridgeway, Cecilia. 2011. Framed by Gender: How Gender Inequality Persists in the Modern World. New York: Oxford University Press. http://dx.doi .org/10.1093/acprof : oso/ 9780199755776.001 .0001$.

Showers, Fumilayo E. 2013. “Gender Race and Nation at Work: African Immigrant Women in Health Care Work in the United States." Paper Presented at the Annual Meetings of the American Sociological Association, New York.

Smeeding, Timothy M., Robert Erikson, and Markus Jäntti, eds. 2011. Persistence, Privilege, and Parenting: The Comparative Study of Intergenerational Mobility. New York: Russell Sage Foundation.

Solon, Gary. 1992. "Intergenerational Income Mobility in the United States." The American Economic Review 82:393-408.

Stacey, Clare L. 2011. The Caring Self: The Work Experiences of Home Care Aides. Ithaca, NY: Cornell University Press.

Treiman, Donald. 1970. "Industrialization and Social Stratification" Pp. 207-234 in Social Stratification: Research and Theory for the 1970s, edited by E. O. Laumann. Indianapolis: Bobbs-Merrill. http://dx.doi.org/10.1111/j.1475-682x.1970.tb01009.x.

U.S. Bureau of the Census. 1971. "1970 Census of Population Classified Index of Industries and Occupations." Washington: U.S. Government Printing Office. 
Weeden, Kim A. 2005. "Stata Algorithm for Backcoding 1980 Census Occupation Codes into 1970 Census Occupation Codes." Unpublished. Department of Sociology, Cornell University.

Weeden, Kim A. and David B. Grusky. 2005. "The Case for a New Class Map." American Journal of Sociology 111:141-212. http://dx . doi .org/10 .1086/428815.

Wilhelm, Mark Ottoni, Eleanor Brown, Patrick Rooney, and Richard Steinberg. 2008. “The Intergenerational Transmission of Generosity. Journal of Public Economics 92:2146-56. http://dx.doi.org/10.1016/j.jpubeco.2008.04.004.

Yang, Yang and Kenneth C. Land. 2008. "Age-Period-Cohort Analysis of Repeated CrossSection Surveys: Fixed or Random Effects?" Sociological Methods E Research 36:297-26. http://dx.doi.org/10.1177/0049124106292360.

Acknowledgements: Equal authors, listed alphabetically. This research was funded by a grant to England and Charles from the Russell Sage Foundation (RSF Project \# 85-1205). We thank Alicia Cast, Erin Cech, Bridget Harr, Alexandra Hendley, Sarah Thébaud, and Catherine Weinberger for comments and suggestions, and Guadalupe Soto for research assistance.

Maria Charles: Department of Sociology, University of California, Santa Barbara. E-mail: mcharles@soc.ucsb.edu.

Corrie Ellis: Department of Sociology, University of California, Santa Barbara. E-mail: corrieellis@umail.ucsb.edu.

Paula England: Department of Sociology, New York University. E-mail: pe22@nyu.edu. 